\title{
Control of pulsatile LH secretion during seasonal anoestrus in the ewe
}

\author{
Jaime Gallegos-Sánchez*, Benoit Malpaux, Jean-Claude Thiéry**
}

Station de physiologie des mammifères domestiques, Inra, 37380 Nouzilly, France

(Received 24 July 1997; accepted 19 January 1998)

\begin{abstract}
The seasonality of reproductive activity in the ewe in temperate latitudes is controlled by photoperiod. Its annual variations control the temporal organization of the sexual cycle by changing the activity of the gonadotrophic axis. Cyclic oestrous behaviour usually appears in the ewe at the end of summer or the beginning of autumn and finishes in winter or at the very beginning of spring. Seasonal anoestrus is characterized by the absence of ovulation and sexual behaviour. During seasonal anoestrus, a decrease in $\mathrm{LH}$ pulse frequency is observed. The inhibition of pulsatile LH secretion is maintained throughout the anoestrous season and is responsible for the low reproductive activity during this period. Variation in the seasonal inhibition of LH pulsatility results from an increase in the negative feedback by oestradiol on LH pulse frequency during the long days of spring and summer. The inhibition of $\mathrm{LH}$ secretion involves increased action of dopamine in the hypothalamus on the chain of nervous elements which controls gonadotrophic activity. Among the various dopaminergic structures, the retrochiasmatic A15 nucleus is involved in the inhibitory control of LH pulsatility by oestradiol during the long day period. Oestradiol increases the dopaminergic tone of the A15 nucleus in ovariectomized ewes during the long day period. In this structure, the effect of oestradiol on the dopaminergic metabolism probably results from a direct, local activation. In the sheep, dopamine might also participate in the inhibition of gonadotrophin activity during other periods of reproductive life. (C) Inra/Elsevier, Paris
\end{abstract}

\section{anoestrus / ewe / hypothalamus / LH pulses / dopamine}

Résumé - Contrôle de la sécrétion pulsatile de LH pendant l'anœestrus saisonnier chez la brebis. Chez la brebis en climat tempéré, l'activité de reproduction est contrôlée par la photopériode, dont les variations annuelles sont responsables des variations d'activité de l'axe gonadotrope hypothalamo-hypophyso-gonadique. Les cycles ostriens de la brebis apparaissent à la fin de l'été et en automne et se terminent à la fin de l'hiver ou au début du printemps. Pendant l'anœstrus saisonnier, il n'y a pas de comportement d'œstrus ni d'ovulation. Durant cette période (jours longs), la sécrétion pulsatile de $\mathrm{LH}$ diminue et se maintient à un niveau de fréquence

* Current address: Colegio de Postgraduados, Programa de Ganaderia, km 35.5 Carretera Mexico-Texcoco, 56230 Montecillo Edo de Mexico, Mexico

** Correspondence and reprints 
basse. Cette fréquence basse est le résultat d'une augmentation forte de la rétroaction négative de l'œstradiol sur la sécrétion pulsatile du LHRH hypothalamique. Cet effet implique la dopamine et spécialement le noyau dopaminergique A15 de l'hypothalamus. À ce niveau, l'œestradiol, qui paraît agir localement, stimule l'activité dopaminergique pendant les jours longs. La dopamine parait également participer à d'autres inhibitions de l'activité gonadotrope chez les ovins. (C) Inra/Elsevier, Paris

ancestrus / brebis / hypothalamus / dopamine

\section{INTRODUCTION}

Under temperate latitudes the reproductive function of the ewe involves a series of physiological events at different times throughout the year. The seasonality of reproductive activity in the ewe is controlled by environmental factors [53], mainly photoperiod, which organize the annual sexual cycle [50]. Ewes have a breeding season, characterized by a succession of 16- to 18-day-long oestrous cycles, which usually appears at the end of summer or the beginning of autumn and finishes in winter or at the very beginning of spring $[20,59,65,81]$. Thereafter follows the anoestrous season, characterized by the absence of ovulation and sexual behavior $[31,53,80,81,94]$.

The change in reproductive status is controlled by modifications in the activity of the gonadotrophic axis through variations in the pulsatile LH secretion. During seasonal anoestrus, a low $\mathrm{LH}$ pulse frequency ( 2 pulses $\times 24 \mathrm{~h}^{-1}$ ) is observed. Inhibition of the pulsatile LH secretion is maintained throughout the anoestrous season and is responsible for the low reproductive activity during this period $[28,56$, 91]. Similarly, in ovariectomized ewes with a subcutaneous $17 \beta$ oestradiol implant, which releases a constant amount of this hormone throughout the year (figure 1), LH pulse frequency is reduced dur-

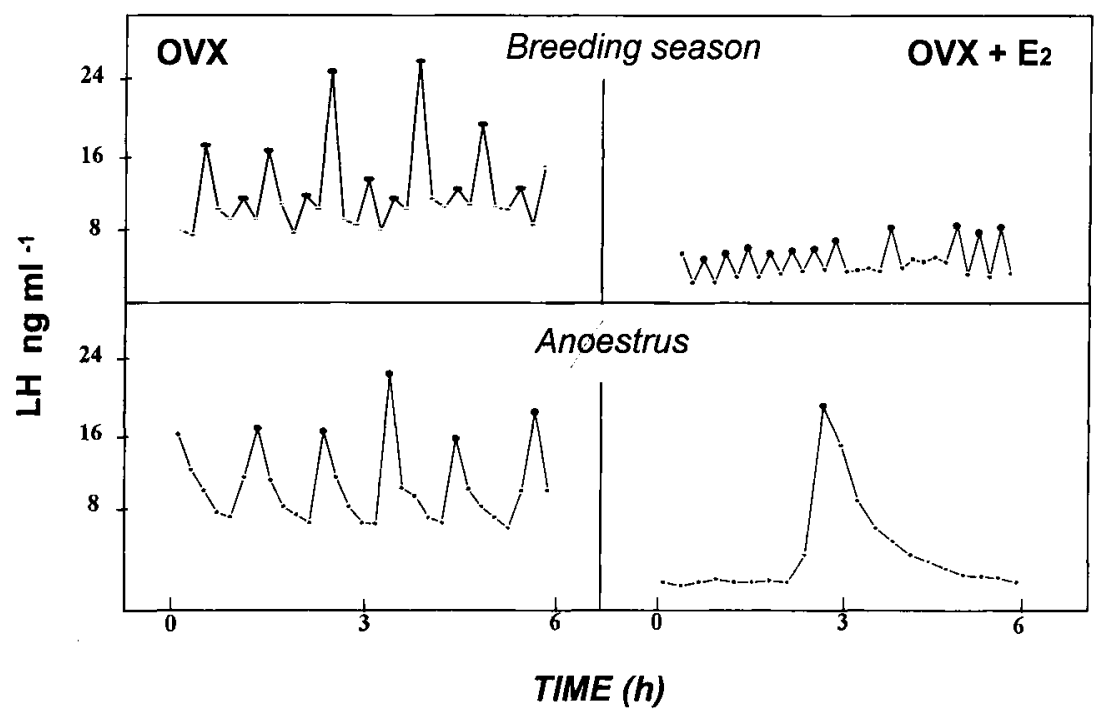

Figure 1. Profiles of plasmatic LH contents observed over $6 \mathrm{~h}$ in the model of ovariectomized ewes bearing (OVX $+\mathrm{E} 2)$ or not (OVX) subcutaneous oestradiol implants. Note the dramatic change in pulsatility in ewes bearing oestradiol implants under anoestrus. Redrawn from Goodman et al. [28]. 
ing the anoestrus of intact females or during constant long days $(16 \mathrm{~L} / 8 \mathrm{D} ;[28,39$, $54,55])$. During the breeding season, the oestradiol implant slightly decreases the amplitude of the pulses without significantly modifying the frequency. Thus the variation in the seasonal inhibition of $\mathrm{LH}$ pulsatility results mainly from an increase in the negative oestradiol feedback on the LH pulse frequency during the long days of spring and summer $[38,44]$. It should also be mentioned that a direct, non-oestradiol-dependent effect of photoperiod on LHRH/LH pulsatility has been clearly demonstrated, but up to now, it appears quantitatively minor [58, 92]. As the secretion of $\mathrm{LH}$ is not spontaneously pulsatile but depends on the pulsatile stimulation of pituitary gonadotrophs by the hypothalamic LHRH, the photoperiodic control of sexual activitity in the ewe concerns the control of the LHRH neurons which release the neurohormone.

The ewe detects photoperiodic variations through melatonin which is secreted at night. The duration of secretion, then, provides information on day length. This hormone acts in the mediobasal hypothalamus to modulate the reproductive activity [51] but the subsequent nervous pathways involved are still unknown. We do know, however, some of the final steps in the chain of nervous response, between the sites of melatonin action and the LHRH cells, which control the gonadotrophic activity. This review presents an update of our current understanding of these neural connections.

\section{NERVOUS REGULATION OF LH RELEASE DURING ANOESTRUS IN THE EWE}

\subsection{Anatomical structures involved}

The immunohistochemical localization of LHRH neurones in the sheep showed that there were a large number of cell bodies in the septal/preoptic areas of the brain (about $60 \%$ of the total population in the brain; $[1,27,37])$. About $15 \%$ of the LHRH neurons are detected in the mediobasal hypothalamus [11]. These could participate in the basal pulsatile LH secretion. The axons of more than $50 \%$ of the LHRH neurons have terminals in the organum vasculosum of the lamina terminalis (OVLT), the others project to the median eminence where they constitute the integration terminal site for the various sources of incoming data which modulate gonadotrophic secretions. Interestingly, it was shown that the LHRH cells from the preoptic area underwent morphological changes in relation to season. Indeed, there are larger dendritic processes during the anoestrous season [46], and an increase of the innervation of the preoptic LHRH elements during the breeding season [93]. However, the involvement of these changes in relation to the inhibition of $\mathrm{LH}$ release during anoestrus remains to be demonstrated.

In the ewe, Domanski et al. [17] and Przekop [63] have shown that lesions in the mediobasal hypothalamus interrupted sexual behaviour and the cyclic activity of the ovaries, while lesions limited to the anterior hypothalamus $(\mathrm{AH})$ can suppress the seasonal anoestrus without blocking the cycle [63]. The identification of monoaminergic structures by immunohistochemical methods also contributed to increasing the understanding of the role of the brain in the seasonality of reproduction in sheep (see Tillet [82] for a review). The anterior part of the hypothalamus, the destruction of which blocks anoestrus contains the retrochiasmatic area where the A15 dopaminergic nucleus is located. In the ovariectomized ewe supplemented with oestradiol, and in the intact ewe during the anoestrous season, the lesions in dopaminergic A15 nuclei [33, 77] and A14 nuclei [33] stimulate LH pul- 
satile secretion. Oestradiol increases the extracellular concentrations of dopamine metabolites and the tyrosine hydroxylase activity of the dopaminergic A15 nucleus in ovariectomized ewes $[24,25]$. Oestradiol also stimulates the nuclear expression of the $c$-fos protein in A14 and A15 nuclei during the long day period [48]. Dopamine from the A15 thus appears as an intermediate in the oestradiol negative feedback loop that affects LH secretion and decreases LH pulsatility during the long day period.

\subsection{Sites of oestradiol action}

The search for central sites of oestradiol action in female mammals, including ewes, mainly focused on positive feedback loops and sexual behaviour but the localizations where the steroid could act negatively during the oestrous cycle or seasonal anoestrus, remain poorly understood. In the ewe, the results of initial studies using intracranial oestradiol implants $[18,52,71]$ have suggested that the mediobasal hypothalamus (MBH) and the $\mathrm{AH}$ play a role in oestrous induction. More recent studies on oestradiol implants in the VMH have shown that this structure is involved in the control of sexual behaviour [7] and the LH preovulatory surge $[7,12]$.

The absence of oestradiol receptors $\left(E_{2} R\right)$ on LHRH neurons should be taken into account to better understand the mode of steroid action on pulsatile LH secretion. This has been shown in the rat [69], the guinea pig [90], the monkey [35] and the ewe $[34,45]$. Steroids probably control the regulation of the pulsatile $\mathrm{LH}$ secretion using intermediate neuronal systems $[21,24,25,58,77,87]$. However in the A15 nucleus, the effect of oestradiol on the dopaminergic metabolism probably results from direct activation. During the anoestrous season or constant long days,
Gallegos-Sánchez et al. [22] used an intracranial implantation technique to show that oestradiol acts directly on the lateral retrochiasmatic area (Rch), especially in the A15 nucleus, to control LH pulsatile secretion. This site of action thus differs from the one that stimulates sexual behaviour or the preovulatory LH surge [7]. Oestradiol implants in the VMH had no effect on LH pulsatility during the long day period in this experiment. It should also be mentioned that the localization of oestradiol activity for the inhibition of LH pulses during the long days in the lower anterior part of the hypothalamus in the ewe is similar to the localization of the inhibitory effects of oestradiol implants on $\mathrm{LH}$ pulsatile release observed in the dopaminergic nucleus from the periventricular anterior area of the hypothalamus in the female rat [3].

In the ewe, the neurons containing $\mathrm{E}_{2} \mathrm{R}$ are mainly localized in the POA, the AH (figure 2), the ventrolateral septum, the bed nucleus of the stria terminalis, the VMH and the arcuate nucleus [8, 34, 47]. Lehman et al. [47] have also detected $\mathrm{E}_{2} \mathrm{R}$ in the amygdala, the hippocampus and the periaqueducal grey matter. Oestradiol receptors are sometimes localized on dopaminergic or endorphine cells in the infundibular A12 nucleus [4, 45], on GABA cells in the preoptic area and on somatostatin cells in the VMH. More recently, distribution of $E_{2} R$ and its possible photoperiodic change was investigated in female sheep under artificial light regimens [72]. There is a localization of $E_{2} R$ in about $25 \%$ of neurones from the A14 nucleus, which is independent of the photoperiod, and no $E_{2} R$ in the A15 nucleus. These data could support the hypothesis of a cascade of events from the A14 to the A15 nucleus, and then to the LHRH system [33]. In contrast, photoperiodic changes in the distribution of $E_{2} R$ involving a larger number of them during the long day period were observed in the 


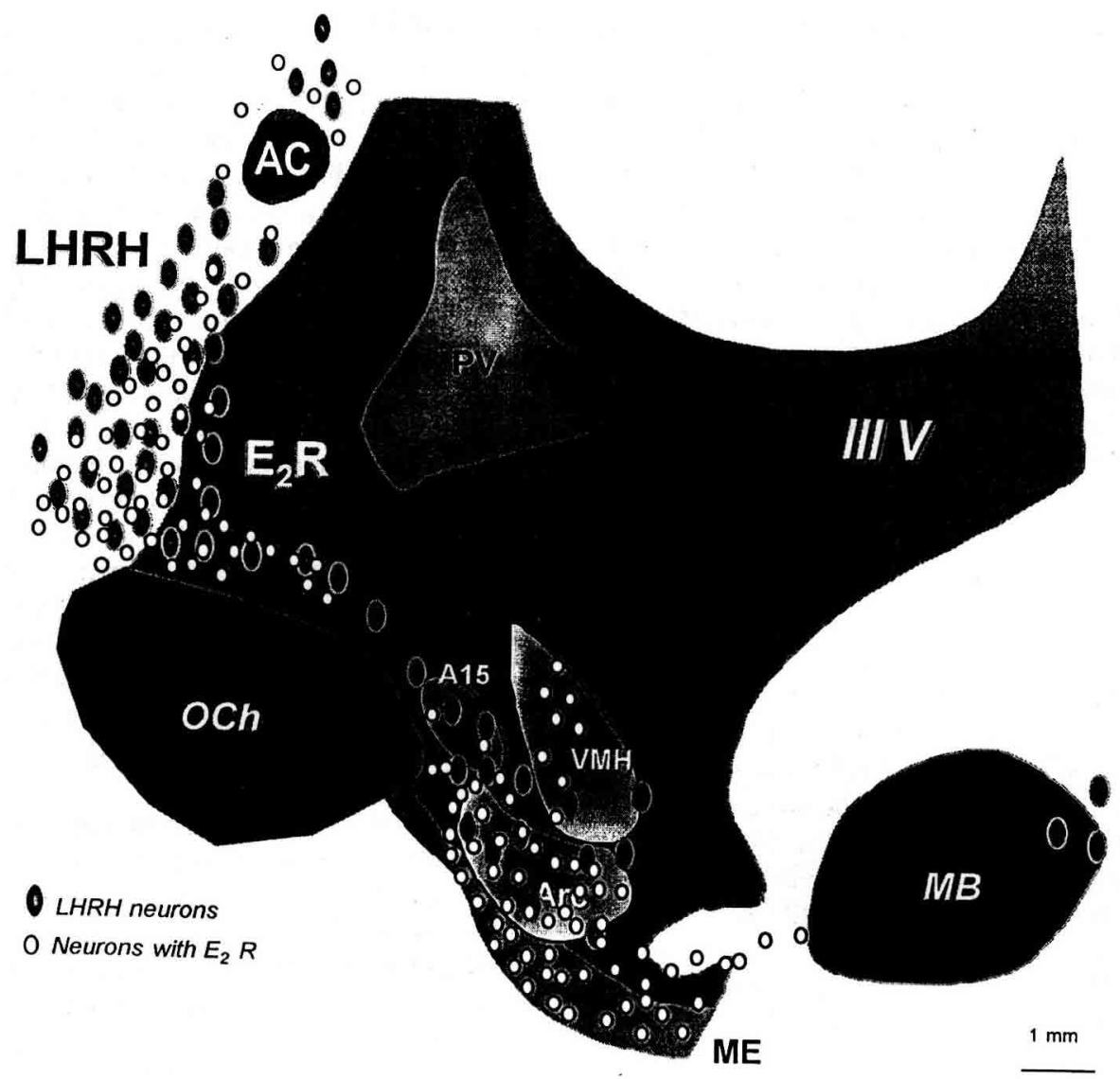

Figure 2. Schematic drawing of the hypothalamus of the sheep showing the distribution of LHRH neurons and the neurons bearing oestradiol receptors. Och, optic chiasma; VMH, ventromedial nucleus; A15, dopaminergic A15 nucleus; PV, paraventricular nucleus; MB, mammilary bodies; Ar, arcuate nucleus; IIIV, third ventricle. Redrawn from Blache and Martin [6].

preoptic area in a study by Skinner and Herbison [72]. The results from our work showing a direct effect of oestradiol in the A15 nucleus [22] either question the role of the receptors from the preoptic area and/or suggest the existence of several mechanisms involved in the regulation of $\mathrm{LH}$ release during the anoestrus.

It should be remembered that a neurochemical lesion of the A15 nucleus by 6hydroxydopamine destroys the catecholaminergic elements, especially the dopaminergic elements and provisionally increases the inhibition of $\mathrm{LH}$ pulsatility during the long day period [77]. A radiofrequency lesion has the same effect but lasts longer [33]. This difference between the effects of the neurochemical versus electrical lesions was interpreted as being due to the intensity of dopaminergic cell destruction. According to our recent results, the greater efficiency of the electrolytic lesions could also be considered as resulting from the destruction of 
non-catecholaminergic elements, cell bodies and axon terminals having presently non-identified $\mathrm{E}_{2} \mathrm{R}$ in $\mathrm{A} 15$.

\subsection{Action of dopamine on the LHRH system}

As in numerous species, the effects of dopamine on LHRH/LH secretion in ewe seem versatile [76]. In sheep, dopamine could participate in the inhibition of gonadotrophic activity before puberty in ewe lambs as well as in the adult ram during anoestrus. In both situations, pimozide and sulpiride, which are two dopaminergic antagonists, stimulate LH secretion [10, $85,86]$. Interestingly, Tortonese and Lincoln [85] propose a working hypothesis suggesting an interaction between dopaminergic and opioidergic inhibition and a change in the balance between both to help in the understanding of the seasonal regulation of $\mathrm{LH}$ secretion in sheep, but the mechanism remains to be established. In adult females, it has been shown that dopamine stimulates the amplitude of LH pulses in the pituitary gland during the breeding season [15] or just after puberty (Thiéry, unpublished data). It should also be mentioned that dopamine could act in the ventromedial hypothalamus of ewe to stimulate prolactin secretion through D1 receptors during the long day period [14]. Nonetheless, the role of dopamine in the regulation of $\mathrm{LH}$ secretion during seasonal anoestrus is the best documented. During the anoestrous season, the systemic injection of pimozide, a dopaminergic antagonist $[57,58]$, stimulates LH secretion. At least in adult ewes during the anoestrous season, the data suggest that dopamine acts on LHRH in the median eminence. For example, the dopamine concentration in tissues and the bioactivity of $\mathrm{TH}$ in the median eminence are higher during the long day period than during the short day period $[75,88]$. Injection of pimozide [32] and alpha-methyl- paratyrosine ( $\alpha$-MPT; [89]) in the median eminence stimulate pulsatile $\mathrm{LH}$ secretion in ovariectomized ewes treated with oestradiol. In the median eminence, the stimulation of $D_{2}$ receptors inhibits $L H$ pulsatility [5]. The dopaminergic inhibition of LHRH cell secretion may consequently be of the presynaptic type and would occur in the terminals of neuron in the median eminence through the $D_{2}$ receptor [13]. However, the role of the A15 nucleus is not directly established for this inhibition in the median eminence since the terminals of this nucleus have only been found in the neurohypophysis [26]. In this structure the dopaminergic activity varies with that of the cell bodies as a function of photoperiodic or steroid conditions (Thiéry, unpublished data). Lesions in A15 lead to decreases in the dopamine contents of the median eminence [78] although its cells do not have any terminals in this structure. It is possible that a synaptic link between the A15 nucleus and the A12 nucleus via 'de passage' fibres exists [26, 48]. In the regulation of LH pulsatility, the A15 nucleus probably only gives a signal passing through the median eminence to amplify the inhibiting activity of the dopaminergic cells from the infundibular nucleus A12, which are, in turn, dependent on photoperiod.

\section{SOME NEUROTRANSMITTERS INVOLVED IN THE REGULATION OF LH SECRETION IN THE EWE DURING ANOESTRUS}

\subsection{Serotonin}

In the ewe, serotonin could play a role in the photoperiod inhibition of $\mathrm{LH}$ secretion [42, 43, 58]. In ovariectomized ewes supplemented with oestradiol, the supply of serotoninergic receptor antagonists, i.e. cyproheptadine and ketanserine, under 
various photoperiodic conditions combined with an inhibition of $\mathrm{LH}$ secretion leads to an increase in the number of $\mathrm{LH}$ pulses [42]. Moreover, similar to catecholamines, extracellular levels of serotonine, and particularly its metabolite 5HIAA, are stimulated by oestradiol in the A15 dopaminergic nucleus [24]. Nevertheless, the stimulating effect of cyproheptadine on LH secretion is also observed in ovariectomized ewes non-supplemented with oestradiol. This suggests that serotonine also plays a role in the mechanisms involved in the photoperiodic regulation of LH secretion that are independent from those of oestradiol $[58,92]$.

\subsection{Noradrenaline}

In the ewe, noradrenaline could participate in the photoperiodic regulation of reproduction $[15,29,57,58,64]$. Meyer and Goodman $[57,58]$ obtained an increase in LH secretion by systemically injecting a noradrenergic antagonist, i.e. phenoxybenzamine, into intact ewes presenting seasonal anoestrus. Moreover, oestradiol increases the intra- and extracellular concentrations of a noradrenaline metabolite, 4-hydroxy-3-methoxyphenylethylene (MHPG) in the A 15 nucleus during the long day period $[24$, $25,75]$. This suggests that noradrenaline may be involved in the establishment of negative feedback by oestradiol on LH secretion in this structure during anoestrus. It has been shown that there is intense innervation of the dopaminergic neurons of the A 15 nucleus by noradrenergic terminals [83]. This innervation originates from noradrenergic cells of the mesencephalic A1 nucleus [84], a structure which presents $E_{2} R$ in the rat [36]. However, the functional role of noradrenaline at this level is still not confirmed since blocking the noradrenergic activity in the A15 nucleus does not prevent either the stimulation of tyrosine hydroxylase $(\mathrm{TH})$ in these cells or the resulting inhibition of LH pulsatility [25].

\subsection{GABA}

As in rodents and primates, GABA could act on LHRH activity in the ewe, especially on its $\mathrm{GABA}_{-\mathrm{A}}$ receptor. During seasonal anoestrus, GABA stimulated the amplitude of $\mathrm{LH}$ pulses, involving $\mathrm{GABA}_{-\mathrm{B}}$ receptors $[66,67]$. In the ovariectomized ewe, introducing a subcutaneous oestradiol implant during the long day period leads to an increase in the GABA concentration in the mediobasal hypothalamus 24 to $48 \mathrm{~h}$ later ([21]; figure 3). Moreover, it should be noted that extracellular GABA concentrations in the retrochiasmatic/A15 nucleus diminish between $48 \mathrm{~h}$ and 9 days later while the LH secretion is totally inhibited and dopaminergic activity is increased [79]. It should also be mentioned that glutamate, a stimulatory amino acid, follows the same time changes in this structure. It remains to be determined whether the opposing variations in levels of these two types of neurotransmitters represent only concomitant phenomena or whether there is a causal relationship.

\section{CONCLUSION AND PERSPECTIVES}

Up to now, of the various neurotransmitters which show modifications in the hypothalamus after oestradiol treatment, only dopamine seems to have a welldemonstrated involvement in the inhibition of $\mathrm{LH}$ pulsatile release during anoestrus in ewe. In the rat, inhibitory actions of dopamine have been shown in vitro as well as in vivo $[19,23]$. Dopamine appears to be an intermediate in the negative feedback by oestradiol and testosterone on LH secretion [2, 16, 74]. It is interesting to note that dopaminergic inhi- 


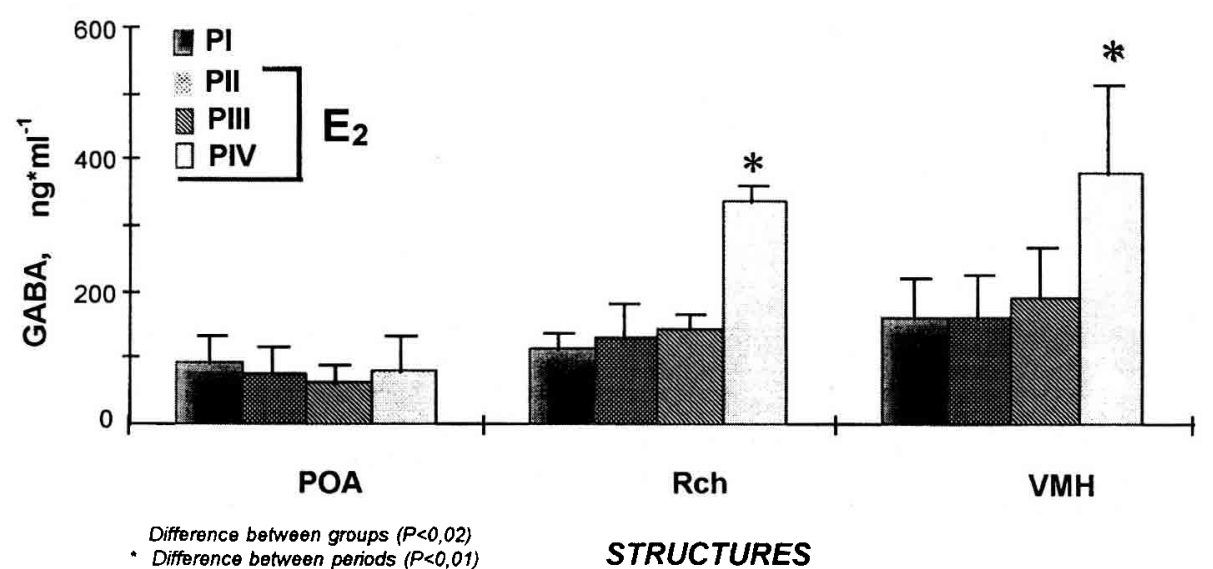

Figure 3. Changes in GABA contents of dialysates obtained in the preoptic area (POA), in the retrochiasmatic area (Rch), and in the ventromedial hypothalamus (VMH) of ovariectomized ewes. PI: before oestradiol infusion through the dialysis probe, PII from 0 to $4 \mathrm{~h}$; PIII from 4 to $8 \mathrm{~h}$ and PIV from 20 to $24 \mathrm{~h}$ after the beginning of the oestradiol infusion. Note the increase in GABA within the Rch and VMH at PIV, when the frequency of LH pulses is beginning to decrease. Modified from Gallegos-Sánchez et al. [21].

bition of gonadotrophin secretion has been demonstrated for other groups of vertebrates (see Thiéry et al. [78] for a review). In fish, especially goldfish, dopamine acts directly on the gonadotrophs by inhibiting the effect of GnRH and also inhibits the secretion of the neuropeptide by a presynaptic inhibition through the $\mathrm{D}_{2}$ receptors [62]. In rainbow trout, oestradiol receptors have been detected in the dopaminergic system inhibiting secretion of GTH2 gonadotrophin [49]. In Rana temporata, dopamine participates in gonadotrophic inhibition during hibernation [73] and, in birds, dopamine can also inhibit GnRH [68]. In these last two examples, a central effect is suggested for dopamine. The A15 nucleus in the ewe seems to maintain two levels of action, i.e. central and pheripheral, but only the central level seems to act in seasonal regulations of gonadotrophic activity.

Current results showing a direct effect of oestradiol implants in the A15 nucleus, where classical steroid receptors (now named $E_{2} R \alpha$ ) have not been shown, raise questions about the local mode of action. According to the lack of effect of oestradiol implants on neighbouring structures such as the VMH, a diffusion of oestradiol from the implant in $A 15$ to the $E_{2} R$ of the close A14 seems unlikely. We need to determine the neuronal and glial cellular types, present in the lateral retrochiasmatic area, on which oestradiol acts. Oestradiol receptors different from those usually described might be involved. A new receptor, called receptor $\beta$, has been recently identified using molecular biological methods [40]. Using an in situ hybridization probe, Shughrue et al. [70] have recently shown the presence of mRNA for this receptor in the CNS. Some localizations are similar to those of receptor $\alpha$, but some hypothalamic sites are different. The steroid may act on the release of a transmitter in a terminal innervating the A15 nucleus. Such phenomena have 
already been described for other regulatory systems by Blaustein et al. [9]. Oestradiol membrane receptors, whose existence seems to be certain [60] can be located on nerve cell terminals. The direct action of oestradiol on the dopaminergic cells of A 15 cannot be excluded. This phenomenon would be similar to that of the nigro-striatal system in the rat [61]. In this study, the phosphorylation of tyrosine hydroxylase is considered as a mode of activation of the enzyme. Phosphorylation is also contemplated as a mode of activation of the cells of the anteroventral periventricular nucleus in the rat [30]. In this nucleus, phosphorylation would concern the CREB protein and would occur before the activation of the cells, especially TH cells. Lagrange et al. [41] have recently shown that oestradiol effects were capable of modifying the electric activity of neurons deprived of receptors, more precisely the LHRH neurones of female guinea pigs. Electrophysiological methods using records of hypothalamic activity can thus be contemplated in the sheep.

Given the absence of terminals in the A15 nucleus of the median eminence and, particularly if the role of other neurotransmitters were to be demonstrated in the future, it could be hypothesized that the dopaminergic nucleus is not the effector or that it may not, in fact, play the inhibitory role that was proposed for it when it was initially identified. Rather, it may form part of an integrative structure participating in the regulation of $\mathrm{LH}$ pulsatility during anoestrus.

\section{REFERENCES}

[1] Advis J.P., Kulis R.O., Dey G.S., Distribution of luteinizing hormone-releasing hormone (LHRH) content and total LHRHdegrading activity (LHRH-DA) in the hypothalamus of the ewe, Endocrinology 116 (1985) 2410-2418.

[2] Aguila-Mansilla N., Kedzierski W., Porter J.C., Testicular inhibition of tyrosine hydrox- ylase expression in tuberoinfundibular and nigrostriatal dopaminergic neurons, Endocrinology 129 (1991) 877-882.

[3] Akema T., Tadakoro Y., Kawakami M., Changes in the characteristics of pulsatile $\mathrm{LH}$ secretion after estradiol implantation into the preoptic area and the basal hypothalamus in ovariectomized rats, Endocrinol. Japon 30 (1983) 281-287.

[4] Batailler M., Blache D., Thibault J., Tillet Y., Immunohistochemical colocalization of tyrosine hydroxylase and estradiol receptors in the sheep arcuate nucleus, Neurosci. Lett. 146 (1992) 125-130.

[5] Bertrand F., Picard S., Thiéry J.C., Malpaux B., Photoperiodic inhibition of LH secretion in the ewe, identification of the dopaminergic receptors implicated in the median eminence, XXVe Colloque de la Société de Neuroendocrinologie Experimentale, Strasbourg, France, 27-28 September, 1996.

[6] Blache D., Martin G.B., Neural and endocrine mechanisms underlying the syncrony of sexual behaviour and ovulation in the sheep, Oxford Rev. Reprod. Biol. 17 (1995) 205-254.

[7] Blache D., Fabre-Nys C.J., Venier G., Ventromedial hypothalamus a a target for oestradiol action on proceptivity, receptivity and luteinizing hormone surge of the ewe, Brain Res. 546 (1991) 241-249.

[8] Blache D., Batailler M., Fabre-Nys C., Oestrogen receptors in the preoptico-hypothalamic continuum, immunohistochemical study of the distribution and cell density during induced oestrous cycle in ovariectomized ewe, J. Neuroendocrinol. 6 (1994) 329-339.

[9] Blaustein J.D., Lehman M.N., Turcotte J.C., Greene G., Estrogen receptors in dendrites and axon terminals in the guinea pig hypothalamus, Endocrinology 131 (1992) 281-290.

[10] Brango C.W., Whisnant C.S., Goodman R., A role of catecholaminergic neurons in the suppression of pulsatile luteinizing hormone secretion in the prepubertal ewe lamb, Neuroendocrinology 52 (1990) 448-484.

[11] Caldani M., Batailler M., Thiéry J.C., Dubois M.P., LH-RH immunoreactive structures in the sheep brain, Histochemistry 89 (1988) 129-139.

[12] Caraty A., Evans N.P., Fabre-Nys C.J., Karsch F.J., The preovulatory gonadotrophinreleasing hormone surge, a neuroendocrine signal for ovulation, J. Reprod. Fertil. (Suppl.) 49 (1995) 245-255.

[13] Curlewis J.D., Naylor A.M., McNeilly A.S., Evaluation of a possible role for the dopamine D1 and D2 receptor in the steroid-dependent suppression of luteinizing hormone secretion 
in the seasonally anoestrus ewe, J. Neuroendocrinol. 3 (1991) 387-391.

[14] Curlewis J.D., Thiéry J.C., Malpaux B., Effect of hypothalamic infusion of a dopamine D-1 receptor antagonist on prolactin secretion in the ewe, Brain Res. 697 (1995) 48-52.

[15] Deaver D.R., Dailey R.A., Effects of dopamine, norepinephrine and serotonin on plasma concentrations of luteinizing hormone and prolactin in ovariectomized and anestrous ewes, Biol. Reprod. 27 (1982) 624-632

[16] Döcke F., Rohdes W., Oelssner W., Schleussner E., Gutenschwager I., Dörner G., Influence of the medial preoptic dopaminergic activity on the efficiency of the negative estrogen feedback in prepubertal and cyclic female rats, Neuroendocrinology 46 (1987) 445-452.

[17] Domanski E., Przekop F., Skubiszewski B., The role of the anterior region of the medial basal hypothalamus in the control of ovulation and sexual behaviour in sheep, Acta Neurobiol. Exp. 32 (1972) 753-762.

[18] Domanski E., Przekop F., Skubiszewski B., Interaction of progesterone and estrogens on the hypothalamic centre controlling estrous behavior in sheep, Acta Neurobiol. Exp. 32 (1972) 763-766.

[19] Drouva S.V., Gallo R.V., Catecholamine involvement in episodic luteinizing hormone release in adult ovariectomized rats, Endocrinology 99 (1976) 651-658

[20] Dyrmundsson O.R., Studies on the breeding season of Icelandic ewes and ewe lambs, J. Agric. Sci. (Camb.) 90 (1978) 275-281.

[21] Gallegos-Sánchez J., Picard S., Delaleu B., Malpaux B., Thiéry J.C., Initiation of oestradiol-induced inhibition of pulsatile LH secretion in ewes under long days, comparison of peripheral versus central treatment and neurochemical correlates, J. Endocrinol. 151 (1996) 19-28.

[22] Gallegos-Sánchez J., Delaleu B., Caraty A., Malpaux B., Thiéry J.C., Estradiol acts locally within the retrochiasmatic area to inhibit pulsatile $\mathrm{LH}$ release in the female sheep during anestrus, Biol. Reprod. 56 (1997) 1544-1549.

[23] Gallo R.V., Drouva S.V., Effects of intraventricular infusion of catecholamines on luteinizing hormone release in ovariectomized and ovariectomized steroid-primed rats, Neuroendocrinology 30 (1979) 149-162.

[24] Gayrard V., Malpaux B., Thiéry J.C., Oestradiol increases the extracellular levels of amine metabolites in the ewe hypothalamus during anoestrus - a microdialysis study, J. Endocrinol. 135 (1992) 421-430.

[25] Gayrard V., Malpaux B., Tillet Y., Thiéry J.C., Estradiol increases tyrosine hydroxylase activity of the A15 nucleus dopaminergic neurons during long days in the ewe, Biol. Reprod. 50 (1994) 1168-1177.

[26] Gayrard V., Thiéry J.C., Thibault J., Tillet Y., Efferent projections from the retrochiasmatic area to the median eminence and to the pars nervosa of the hypophysis with special reference to the A15 dopaminergic cell group in the sheep, Cell Tissue Res. 281 (1995) 561-567.

[27] Glass J.D., Mastran T., Nett T.M., Effects of estradiol and progesterone on the gonadotropin-releasing hormone (GnRH)immunoreactive neuronal system of the anestrous ewe, Brain Res. 381 (1986) 336-344.

[28] Goodman R.L., Bittman E.L., Foster D.L., Karsch F.J., Alterations in the control of luteinizing hormone pulse frequency underlie the seasonal variation in estradiol negative feedback in the ewe, Biol. Reprod. 27 (1982) 580-589.

[29] Goodman R.L., Robinson J.E., Kendrick K.M., Dyer R.G., Is the inhibitory action of estradiol on luteinizing hormone pulse frequency in anestrous ewes mediated by noradrenergic neurons in the preoptic area? Neuroendocrinology 61 (1995) 284-292.

[30] Gu Q., Rojo A.A., Zee M.C., Yu J., Simerly R.B., Hormonal regulation of CREB phosphorylation in the anteroventral periventricular nucleus, J. Neurosci. 16 (1996) 3035-3044.

[31] Hafez E.S.E., Studies on the breeding season and of reproduction in the ewe, J. Agric. Sci. (Camb.) 42 (1952) 189-265

[32] Havern R.L., Whisnant C.S., Goodman R.L., Hypothalamic sites of catecholamine inhibition of luteinizing hormone in the anestrous ewes, Biol. Reprod. 44 (1991) 476-482.

[33] Havern R.L., Whisnant C.S., Goodman R.L., Dopaminergic structures in the ovine hypothalamus mediating estradiol negative feedback in anestrous ewes, Endocrinology 134 (1994) 1905-1914.

[34] Herbison A.E., Robinson J.E., Skinner D.C., Distribution of estrogen receptor-immunoreactive cells in the preoptic area of the ewe co-localization with glutamic acid decarboxylase but not luteinizing hormone-releasing hormone, Neuroendocrinology 57 (1993) $751-759$.

[35] Herbison A.E., Horvath T.L., Naftolin F., Leranth C., Distribution of oestrogen receptor-immunoreactive cells in monkey hypothalamus, relationship to neurones containing luteinizing hormone-releasing hormone and tyrosine hydroxylase, Neuroendocrinology 61 (1995) 1-10.

[36] Heritage A.S., Grant L.D., Stumpf W., 3Hestradiol in catecholamine neurons of rat brain 
stem, combined localization by autoradiographic formaldehyde-induced fluorescence, J. Comp. Neurol. 176 (1977) 607-630.

[37] Jansen H.T., Hileman S.M., Lubbers L.S., Kuehl D.E., Jackson G.L., Lehman M.N., Indentification and distribution of neuroendocrine gonadotropin-releasing hormone neurons in the ewe, Biol. Reprod. 56 (1997) 655-662.

[38] Karsch F.J., Goodman R.L., Legan S.J., Feedback basis of seasonal breeding, test of an hypothesis, J. Reprod. Fertil. 58 (1980) 521-535.

[39] Karsch F.J., Bittman E.L., Robinson J.E., Yellon S.M., Wayne N.L., OIster D.H., Kaynard A.H., Melatonine and photorefractoriness, los of response to the melatonine signal leads to seasonal reproductive transitions in the ewe, Biol. Reprod. 34 (1986) 265-274.

[40] Kuiper G.G.J.M., Enmark E., Pelto-Huikko M., Nilsson S., Gustafsson J.A., Cloning of a novel estrogen receptor expressed in rat protastate and ovary, Proc. Natl. Acad. Sci. 93 (1996) 5925-5930.

[41] Lagrange A.H., Ronnekleiv O.K., Kelly M.J., Estradiol-1 7 beta and mu-opioid peptides rapidly hyperpolarize $\mathrm{GnRH}$ neurons, A cellular mechanism of negative feedback? Endocrinology 136 (1995) 2341-2344.

[42] Le Corre S., Chemineau P., Control of photoperiodic inhibition of luteinizing hormone secretion by dopaminergic and serotonergic systems in ovariectomized Ile-de-France ewes supplemented with oestradiol, J. Reprod. Fertil. 97 (1993) 367-373.

[43] Le Corre S., Chemineau P., Serotonergic 5HT(2)-receptors mediate the inhibitory action of serotonin on luteinizing hormone secretion in ovariectomized, estradiol-treated ewes that are refractory to short days, Biol. Reprod. 49 (1993) 140-147.

[44] Legan S.J., Karsch F.J, Neuroendocrine regulation of the estrous cycle and seasonal breeding in the ewe, Biol. Reprod. 20 (1979) 74-85.

[45] Lehman M.N., Karsch F.J., Do gonadotropinreleasing hormone, tyrosine hydroxylaseimmunoreactive, and beta-endorphinimmunoreactive neurons contain estrogen receptors? A double-label immunocytochemical study in the suffolk ewe, Endocrinology 133 (1993) 887-895.

[46] Lehman M.N., Robinson J.E., Karsch F.J., Silverman A.J., Immunocytochemical localization of luteinizing hormone-releasing hormone (LHRH) pathways in the sheep brain during anoestrus and the mid-luteal phase of the estrous cycle, J. Comp. Neurol. 244 (1986) 19-35.
[47] Lehman MN, Ebling FJP, Moenter SM, Karsch FJ (1993) Distribution of estrogen receptor-immunoreactive cells in the sheep brain, Endocrinology 133, 876-886.

[48] Lehman M.N., Durham D.M., Jansen H.T., Adrian B., Goodman R.L., Dopaminergic A14/A15 neurons are activated during estradiol negative feedback in anestrous, but not breeding season ewes, Endocrinology 137 (1996) 4443-4450.

[49] Linard B., Anglade I., Corio M., Navas J.M., Pakdel F., Saligaut C., Kah O., Estrogen receptors are expressed in a subset of tyrosine hydroxylase-positive neurons of the anterior preoptic region in the Rainbow Trout, Neuroendocrinology 63 (1996) 156-165.

[50] Malpaux B., Robinson J.E., Wayne N.L., Karsch F.J., Regulation of the onset of the breeding season of the ewe, importance of long days and of an endogenous reproductive rhythm, J. Endocrinol. 122 (1989) 269-278.

[51] Malpaux B., Daveau A., Maurice F., Gayrard V., Thiéry J.C., Short days effects of melatonin on luteinizing hormone secretion in the ewe: evidence for a central site of action in the mediobasal hypothalamus, Biol. Reprod. 48 (1993) $752-760$

[52] Malven P.V., Coppings R.J., Brain sites stimulatory to release of luteinizing hormone, comparative effects of localized estrogenic and electrical stimuli in conscious sheep, Brain Res. 125 (1977) 175-181.

[53] Marshall F.H.A., On the change over in the oestrous cycle in animals after transference across the equator, with further observations on the incidence of the breeding seasons and the factors controlling sexual periodicity, Proc. Roy. Soc. London (B) 122 (1937) 413-428.

[54] Martin G.B., Factors affecting the secretion of luteinizing hormone in the ewe, Biol. Rev. 59 (1984) 1-86.

[55] Martin G.B., Scaramuzzi R.J., Henstridge J.D., Effects of oestradiol, progesterone and androstenedione on the pulsatile secretion of luteinizing hormone in ovariectomized ewes during spring and autumn, J. Endocrinol. 96 (1983) 181-193.

[56] McLeod B.J., Haresign W., Lamming G.E., The induction of ovulation and luteal function in seasonally anoestrous ewes treated with small-dose multiple injections of $\mathrm{GnRH}$, J. Reprod. Fertil. 65 (1982) 215-221.

[57] Meyer S.L., Goodman R.L., Neurotransmitters involved in mediating the steroid-dependent suppression of pulsatile luteinizing hormone secretion in anoestrous ewes, effects 
of receptors antagonists, Endocrinology 116 (1985) 2054-2061.

[58] Meyer S.L., Goodman R.L., Separate neural systems mediate the steroid-dependent and steroid-independent suppression of tonic luteinizing hormone secretion in the anoestrous ewe, Biol. Reprod. 35 (1986) 562-571.

[59] Ortavant R., Pelletier J., Ravault J.P., Thimonier J., Volland-Nail P., Photoperiod, main proximal and distal factor of the circannual cycle of reproduction in farm animals, Oxford Rev. Reprod. Biol. 7 (1985) 305-345.

[60] Pappas C.P., Gametchu B., Watson C.S., Membrane estrogen receptors identified by multiple antibody labeling and imbedded-ligand binding, FASEB J. 9 (1995) 404-401.

[61] Pasqualini C., Olivier V., Guibert B., Frain O., Leviel V., Acute stimulatory effect of estradiol on striatal dopamine synthesis, $\mathbf{J}$. Neurochem. 65 (1995) 1651-1657.

[62] Peter R.E., Trudeau V.L., Sloley B.D., Peng C., Nahorniak C.S., Actions of catecholamines, peptides and sex steroids in regulation of gonadotropin-II in the Goldfish, in: Scott A.P., Sumpe J.P., Kime D.E., Rolfe M.S. (Eds.), Proceedings of the Fourth International Symposium on the Reproductive Physiology of Fish., Fishsymp, Sheffield, 1991, pp. 30-34.

[63] Przekop F., Effect of anterior deafferentation of the hypothalamus on the release of luteinizing $(\mathrm{LH})$ and reproduction in sheep, Acta Physiol. Pol. 29 (1978) 293-407.

[64] Przekop F., Skubiszewski B., Wolinska E., Domanski E., The role of catecholamines in stimulating the release of pituitary ovulating hormone(s) in sheep, Acta Physiol. Pol. 26 (1975) 433-437.

[65] Robinson J.E., Karsch F.J., Refractoriness to inductive day lengths terminates the breeding season of the Suffolk ewe, Biol. Reprod. 31 (1984) 656-663.

[66] Scott C.J., Clarke I.J., Evidence that changes in the function of the subtypes of the receptors for gamma-amino butyric acid may be involved in the seasonal changes in the negative-feedback effects of estrogen on gonadotropin-releasing hormone secretion and plasma luteinizing hormone levels in the ewe, Endocrinology 133 (1993) 2904-2912.

[67] Scott C.J., Clarke I.J., Inhibition of luteinizing hormone secretion in ovariectomized ewes during breeding season by G-Aminobutiric acid (GABA) is mediated by GABA-A receptors, but not GABA-B receptors, Endocrinology 132 (1993) 1789-1796.

[68] Sharp P.J., Talbot R.T., MacNamee M.C., Evidence for the involvement of dopamine and 5-hydroxytryptamine in the regulation of the preovulatory release of luteinizing hormone in the domestic hen, Gen. Comp. Endocrinol. 76 (1989) 205-213.

[69] Shivers B.D., Harlan R.E., Morell J.I., Pfaff D.W., Absence of oestradiol concentration in cell nuclei of LHRH-immunoreactive neurones, Nature 304 (1983) 345-347.

[70] Shughrue P.J., Komm B., Merchenthaler I., The distribution of estrogen receptor-b mRNA in the rat hypothalamus, Steroids 61 (1996) 678-681.

[71] Signoret J.P., Action d'implants de benzoate d'œstradiol dans l'hypothalamus sur le comportement d'œstrus de la brebis ovariectomisée, Ann. Biol. Anim. Biochim. Biophys. 10 (1970) 549-566.

[72] Skinner D.C., Herbison A.E., Effects of photoperiod on estrogen receptor, tyrosine hydroxylase, neuropeptide $\mathrm{Y}$, and $\mathrm{B}$-endorphin immunoreactivity in the ewe hypothalamus, Endocrinology 138 (1997) 2585-2595.

[73] Sotowska-Brochocka J., Martynska L., Licht P., Dopaminergic inhibition of gonadotropic release in hibernating frogs, Rana temporata, Gen. Comp. Endocrinol. 93 (1994) 192-1969.

[74] Tadakoro Y., Akema T., Kimura F., Dopaminergic involvement in the estrogeninduced suppression of frequency of pulsatile luteinizing hormone secretion in the ovariectomized rat, Brain Res. 380 (1986) 69-75.

[75] Thiéry J.C., Monoamine content of the stalkmedian eminence and hypothalamus in adult female sheep as affected by daylength, J. Neuroendocrinol. 3 (1991) 407-411.

[76] Thiéry J.C., Martin G.B., Neurophysiological control of the secretion of gonadotrophinreleasing hormone and luteinizing hormone in the sheep - A review, Reprod. Fertil. Develop. 3 (1991) 137-173.

[77] Thiéry J.C., Martin G.B., Tillet Y., Caldani M., Quentin M., Jamain C., Ravault J.P., Rôle of hypothalamic catecholamines in the regulation of LH and prolactin secretion in the ewe during seasonal anoestrus, Neuroendrocrinology 49 (1989) 80-87.

[78] Thiéry J.C., Gayrard V., Le Corre S., Viguié C., Martin G.B., Chemineau P., Malpaux B., Dopaminergic control of $\mathrm{LH}$ secretion by the A15 nucleus in anoestrous ewes, J. Reprod. Fertil. (Suppl) 49 (1995) 199-220.

[79] Thiéry J.C., Gallegos-Sánchez J., Picard S., Malpaux B., Inhibition de la pulsatilité de LH en jours longs chez la brebis: effets précoces et tardifs de l'oestradiol sur les neurotransmetteurs prélevés par microdialyse dans l'hypothalamus, 3 e Colloque de la société des neurosciences, Bordeaux, 25-28 May 1997 (abst. D41). 
[80] Thimonier J., Contrôle photopériodique de l'activite ovulatoire chez la brebis, existence de rythmes endogenes, thèse DSc, Université François Rabelais de Tours, France, 1989.

[81] Thimonier J., Mauléon P., Variations saisonnières du comportement d'oestrus et des activités ovarienne et hypophysair chez les ovins, Ann. Biol. Anim. Biochim. Biophys. 9 (1969) 233-250.

[82] Tillet Y., Distribution of neurotransmitters in the sheep brain, J. Reprod. Fertil. (Suppl.) 49 (1995) 199-220.

[83] Tillet Y., Thibault J., Morphological relationships between tyrosine hydroxylaseimmunoreactive neurons and dopamine-betahydroxylase-immunoreactive fibres in dopamine cell group-A15 of the sheep, J. Chem. Neuroanat. 6 (1993) 69-78.

[84] Tillet Y., Gayrard V., Thibault J., Noradrenergic afferences to the retrochiasmatic area in the hypothalamus of the sheep, 16th. Meeting of the European Neurosciences Association, Madrid, Spain, 1993 (abst.) p. 60.

[85] Tortonese D.J., Lincoln G.A., Photoperiodic modulation of the dopaminergic control of pulsatile LH secretion in sheep, J. Endocrinol. 143 (1994) 25-32.

[86] Tortonese D.J., Lincoln G.A., Effects of melatonin in the mediobasal hypothalamus on the secretion of gonadotrophins in sheep, role of dopaminergic pathways, J. Endocrinol. 146 (1995) 543-552.

[87] Viguié C., Caraty A., Locatelli A., Malpaux B., Regulation of luteinizing hormone-releasing hormone (LHRH) secretion by melatonin in the ewe II. Changes in N-methyl-D, Laspartic acid-induced LHRH release during the stimulation of luteinizing hormone secretion by melatonin, Biol. Reprod. 52 (1995) 1156-1161.
[88] Viguié C., Thibault J., Thiéry J.C., Tillet Y., Malpaux B., Photoperiodic modulation of monoamines and amino-acids involved in the control of prolactin and L.H secretion in the ewe, evidence for a regulation of tyrosine hydroxylase activity, J. Neuroendocrinol. 8 (1996) 465-474.

[89] Viguié C., Thiéry J.C., Picard S. , Malpaux $B$., Blockade of tyrosine hydroxylase in the median eminence stimulates $\mathbf{L H}$ pulsatile secretion in long-day treated ewes, Biol. Reprod. 52 (Suppl. 1) (1996) 155.

[90] Watson R.E., Langub M.C., Andis J.W., Further evidence that most luteinizing hormonereleasing hormone neurons are not directly estrogen-responsive-simultaneous localization of luteinizing hormone-releasing hormone and estrogen receptor immunoreactivity in the guinea-pig brain, J. Neuroendocrinol. 4 (1992) 311-317.

[91] Webb R., Baxter G., McBride D., Ritchie M., Springbett A.J., Mechanism controlling ovulation rate in ewes in relation to seasonal anoestrus, J. Reprod. Fertil. 94 (1992) 143-151.

[92] Whisnant C.S., Goodman R.L., Further evidence that serotonin mediates the steroidindependent inhibition of luteinizing hormone secretion in anestrous ewes, Biol. Reprod. 42 (1990) 656-661.

[93] Xiong J.J., Karsch F.J., Lehman M.N., Evidence for seasonal plasticity in the gonadotropin-releasing hormone (GnRH) system of the ewe: Changes in synaptic inputs onto GnRH neurons, Endocrinology 138 (1997) 1240-1250.

[94] Yeates N.T.M., The breeding season of the sheep with particular reference to its modification by artificial light, J. Agric. Sci. (Camb.) 39 (1949) 1-43. 